\title{
Antimicrobial Activity of Endophytic Fungi Isolated from Avicennia marina Plant, Red Sea, Egypt
}

Y. M. Shebany

Botany Department, Faculty of Science at Qena, South Valley

University, Qena, Egypt.

TWENTY ONE endophytic species were isolated from 360

segments of Avicennia marina from two different locations of Red Sea mangrove forest in 2009 to 2010. Some of the endophytes were identified to genus or species level using traditional morphological methods, but most were classified as sterile mycelia. The isolated species belonged to 7 genera (Acromonium, Aspergillus, Chaetomium, Cladosporium, Fusarium, Phoma and Ulocladium). Thirty nine isolates of endophytic fungi were selected to detected their antagonistic abilities against Bacillus subtilis, Staphylococcus aureus, Micrococcus luteus, Escherichia coli, Aspergillus niger and Alternaria alternate. The obtained results indicated that some isolates of the same species showed different behavior against used bacteria, while few of these isolates of the same species showed the same behavior. The tested endophytic species did not show any antagonistic ability against Aspergillus niger and Alternaria alternate.

Keyword: Avicennia marina, Mangrove, Endophytic fungi, Antimicrobial activity.

Mangrove forests are worldwide distributed on sheltered, tropical and subtropical coastlines (Ellison \& Farnsworth, 2001 and Lin et al., 2009). Mangrove forests are located at the interface between land and sea, a unique and extreme environment (Kathiresan \& Bingham, 2001 and Ezawa \& Tada, 2009). The mangroves of the world span over 30 tropical and sub-tropical countries, covering an area of about 99,300 sq. km (Singh, 2000). On the global level, several authors reviewed the past and present distribution of mangrove ecosystem (Tomlinson, 1986; Ricklefs \& Latham, 1993; Dunk et al., 1998 and Ellison et al., 1999). Mangrove areas in Egypt are dispersed in numerous small sites along the Red Sea Coast, although the overall area of mangroves is relatively small. The present estimates indicate that there are approximately $5 \mathrm{~km}^{2}$ of mangroves in Egypt. The limited mangrove areas of Egypt suggest that this is a vulnerable ecosystem that needs effective management to ensure its ongoing survival (Saenger, 2002). 
The soils in mangrove communities are muddy or sandy with loose sediments. They contain submerged mangrove roots, trunks and branches. These conditions attract rich communities of fungi and bacteria (Kathiresan \& Bingham, 2001). Among the microorganisms, the fungal community is the principal degrader of plant debris, especially during the early phases of decomposition. Therefore, fungi play an important role in the transformation and cycling of nutrients in the ecosystem (Zakaria et al., 2010).

Endophytic microorganisms colonize living, internal tissues of the plants without causing any immediate, overt negative effects (Bacon \& White, 2000; Wasser, 2002 and Sun et al., 2011). Endophytes have proved to be the promising sources of biologically active products which are of interest for specific medicinal applications (Strobel, 2002).

Endophytic fungal association with mangrove plants confers protection from adverse environmental conditions and allows them to successfully compete with saprobic fungi decomposing senescent parts (Kumaresan \& Suryanarayanan, 2002). Leaves, stems, bark, roots and fruits of mangrove plants are a valuable resource for folk medicine (Bandaranayake, 1998). He showed that roots of mangrove plants are a rich source of fungal endophytes (Ananda \& Sridhar, 2002). Metabolites exploited in pharmaceutical and agricultural industries are widespread among the endophytic fungi (Petrini et al., 1992 and Li et al., 2008 ).

Marine mangrove fungi have proven to be an important source of new bioactive compounds (Lin et al., 2001) and enzymes (Grant et al., 1996; Pointing et al., 1998 and Pointing \& Hyde, 2000). Endophytes might involve in decomposition when the tissue becomes senescent or die. Hence, they elaborate the enzymes necessary for degradation of lignocellulosic materials.

Since Avicennia marina constituted the dominant species in the Egyptian mangrove forests, therefore, the present work aimed to isolate endophytic mycobiota of this plant and detect their anatagonistic abilities against some pathogenic microorganisms.

\section{Study area}

\section{Materials and Methods}

The Red Sea comprises the main part of the East African rift valley. It lies between latitudes $30^{\circ} 58^{\prime} \mathrm{N}$ and $12^{\circ} 30^{\prime} \mathrm{N}$. The climate is arid, rainfall is Mediterranean (in the winter), daily temperature maximum is $27{ }^{\circ} \mathrm{C}$ in May, humidity is about $50 \%$ and the tidal range is small. The coast mostly consists of vertically raised $(30-40 \mathrm{~m})$ fossil cliffs and wide horizontal expanses of beach rocks, producing intertidal flat cover of $100 \mathrm{~m}$ in width. The intertidal zone is particularly harsh, with very high solar heating and desiccation stress, and a very low tidal range. It contains all major tropical marine communities, except estuaries. These conditions are suitable for the growth of mangrove and other coastal vegetation. 


\section{Isolation of endophytic fungi}

30 samples of Avicennia marina were surveyed for fungal endophytes. Respiratory roots were collected from regions 17 and 40 from the coastal of Red Sea. Samples were transported in closed sterile polythene bags and, were processed within $24 \mathrm{hr}$ of collection (Fisher \& Petrini, 1987)

\section{Surface sterilization, culture condition and isolation}

The Respiratory roots segments were cut into four segments each of one $\mathrm{cm}$ length and washed in running tap water to remove surface contamination and were dipped in $75 \%$ ethanol (1 min), 5\% sodium hypochlorite ( $3 \mathrm{~min}$ ) and $75 \%$ ethanol (0.5 $\mathrm{min})$ followed by rinse in sterile distilled water (Filip et al., 2003). Segments were placed on $20 \mathrm{ml} \mathrm{CZ}$ medium in a petri dish and were incubated at $28^{\circ} \mathrm{C} \pm 1{ }^{\circ} \mathrm{C}$ for $2-3$ weeks (Carroll, 1986). The fungi that grew out from the plant tissues were periodically observed through a microscope. The endophytic fungi were identified with the help of keys (Sutton, 1980; Howksworth et al., 1983; Nelson et al., 1983 and Von Arx et al.,1986). The sterile Mycelia that grew out from the tissue were subcultured on $\mathrm{CZ}$ slant and exposed to light to induce sporulation (Suryanarayanan, 1992).

\section{Antimicrobial assay}

Fermentation and treatment of the fermentation broth

The endophytic fungi were transfered to $100 \mathrm{ml}$ of GPY medium (GPY: glucose $20 \mathrm{~g} / \mathrm{L}$, peptone $5 \mathrm{~g} / \mathrm{L}$, yeast extract $5 \mathrm{~g} / \mathrm{L}$ ) in Erlenmeyer flasks and incubated at $28^{\circ} \mathrm{C}$ and $160 \mathrm{rpm}$ with normal daily light and dark periods for 10 days. The mycelia of the endophytic fungi were separated by filtering with Whatman filter paper. The mycelial mass was also separated from the broth by filtration, and the culture broth was partitioned with chloroform. After that the organic solvents were evaporated under vacuum (Ding et al., 2010 and Ramos et al., 2010).

\section{Microorganisms used}

The tested bacteria were obtained from bacteriology lab, and fungi from mycology lab., Botany Dept., Faculty of Sciences, South Valley University.

\section{Antimicrobial activity}

Antibacterial tests of selected microorganisms were carried out using discdiffusion method (Bauer et al., 1966). Nutrient agar plates $(90 \mathrm{~mm}$ size) were prepared and cooled down at room temperature $\left(20 \pm 2^{\circ} \mathrm{C}\right)$. A small sterile cotton swab was dipped into the $24 \mathrm{hr}$ old culture of bacteria (Bacillus subtilis, Staphylococcus aureus, Micrococcus luteus and Escherichia coli) and was inoculated by streaking the swab over the entire agar surface. This process was repeated by streaking the swab 2 or more times rotating the plates approximately $60^{\circ}$ each time to ensure even distribution of inoculum. After inoculation the plates were allowed to dry at room temperature $\left(20 \pm 2^{\circ} \mathrm{C}\right)$ for $15 \mathrm{~min}$ in laminar chamber for settle down of inoculum. The filter paper discs $(5 \mathrm{~mm})$ loaded with $10 \mu$ of extract were placed on the surface of the bacteria seeded agar plates and it was allowed to diffuse for $5 \mathrm{~min}$, then these plates were incubated at $37 \pm 1^{\circ} \mathrm{C}$ for $24 \mathrm{hr}$. Two fungal species ( Alternaria alternata and Aspergillus niger) were employed, and the plates 
were incubated at $28^{\circ} \mathrm{C}$ up to 5-7 days (Maria et al., 2005). Chloroamphenicol ( $1 \mathrm{x}$ $\left.10^{-3}\right)$, tetracycline $\left(1 \times 10^{-3}\right)$ and for fungal species kemazed $50 \%$ ( methyl benzimidazol-2-ylcarbamate $)\left(1 \times 10^{-3}\right)$ were placed into agar plates used as positive control and respective solvent were also used as negative control.

\section{Results}

Eleven species belonging to 7 genera and 10 sterile mycelia were isolated and identified from the respiratory roots of 30 samples (15 from each region 17 \& 40) of Avicennia marina (Table 1).

TABLE 1. Total fungal count (TC) and percentage of occurrence of fungi from the endorhizosphere of Avicennia marina of regions 17 and 40 of the costal Red Sea.

\begin{tabular}{|l|c|c|c|c|c|c|}
\hline \multirow{2}{*}{ Genera and species } & \multicolumn{3}{|c|}{ Region 17 } & \multicolumn{3}{c|}{ Region 40 } \\
\cline { 2 - 7 } & T C & C \% & S \% & TC & C\% & S \% \\
\hline Acromonium sp. & 5 & 3.73 & 2.78 & 1 & 1.41 & 0.56 \\
\hline Aspergillus & 7 & 5.22 & 3.89 & 19 & 26.76 & 10.56 \\
\hline A.flavus & 0 & 0 & 0 & 7 & 9.86 & 3.89 \\
\hline A. nidulans & 0 & 0 & 0 & 7 & 9.86 & 3.89 \\
\hline A.niger & 1 & 0.75 & 0.56 & 4 & 5.63 & 2.22 \\
\hline A.terreus & 4 & 2.99 & 2.22 & 1 & 1.41 & 0.56 \\
\hline A. sydewi & 2 & 1.49 & 1.11 & 0 & 0 & 0 \\
\hline Chaetomium globosum & 6 & 4.48 & 3.33 & 0 & 0 & 0 \\
\hline $\begin{array}{l}\text { Cladosporium } \\
\text { cladosporides }\end{array}$ & 3 & 2.24 & 1.67 & 0 & 0 & 0 \\
\hline Fusarium moniliforme & 3 & 2.24 & 1.67 & 0 & 0 & 0 \\
\hline Phoma sp. & 4 & 2.99 & 2.22 & 10 & 14.08 & 5.56 \\
\hline Ulocladium sp. & 0 & 0 & 0 & 1 & 1.41 & 0.56 \\
\hline Sterile mycelium & 106 & 79.1 & 58.88 & 40 & 56.34 & 22.22 \\
\hline Sterile mycelium 1 & 5 & 3.73 & 2.78 & 14 & 19.72 & 7.77 \\
\hline Sterile mycelium 2 & 3 & 2.24 & 1.67 & 4 & 5.63 & 2.22 \\
\hline Sterile mycelium 3 & 6 & 4.48 & 3.33 & 6 & 8.45 & 3.33 \\
\hline Sterile mycelium 4 & 33 & 24.63 & 18.33 & 7 & 9.86 & 3.89 \\
\hline Sterile mycelium 5 & 39 & 29.1 & 21.67 & 2 & 2.82 & 1.11 \\
\hline Sterile mycelium 6 & 1 & 0.75 & 0.55 & 3 & 4.23 & 1.67 \\
\hline Sterile mycelium 7 & 12 & 8.95 & 6.66 & 0 & 0 & 0 \\
\hline Sterile mycelium 8 & 0 & 0 & 0 & 1 & 1.41 & 0.56 \\
\hline Sterile mycelium 9 & 0 & 0 & 0 & 3 & 4.22 & 1.67 \\
\hline Sterile mycelium 10 & 7 & 5.22 & 3.89 & 0 & 0 & 0 \\
\hline Total account & 134 & 100 & 74.44 & 71 & 100 & 39.46 \\
\hline total segments & 180 & 100 & 100 & 180 & 100 & 100 \\
\hline TC canculated per 180 & & & & & 0 \\
\hline
\end{tabular}

TC = calculated per 180 segments, $\mathrm{C} \%=$ calculated per total fungi, $\mathrm{S} \%=$ calculated per total segments sporulating.

Egypt. J. Microbiol. 47 (2012) 
Sterile mycelia were the most dominant fungal taxa identified during this experiment, where 8 sterile mycelia were isolated from each region. Total counts were fluctuated from 106 to 134 and 40 to 71 colony/segment, represented $79.1 \%$ and $56.34 \%$ of total fungi and $58.88 \%$ and $22.22 \%$ of total segments from regions 17 and 40, respectively (Table 1 ).

Data of Table 1 also showed that, Aspergillus sp. was the second most common genus in count which recovered from regions 17 \& 40 comprised $5.22 \% \& 26.76 \%$ of total colonies and $3.89 \% \& 10.56 \%$ of total segments, respectively.

Phoma sp. was also isolated from the two regions comprised $2.99 \%$ and $14.08 \%$ of total colonies and $2.22 \%$ and $5.56 \%$ of total segments, respectively. Chaetomium globosum, Cladosporium cladosporioides and Fusarium moniliform were isolated only from region 17 which comprised $4.48 \%, 2.24 \%$ and $2.24 \%$ of total colonies and $3.33 \%, 1.67 \%$ and $1.67 \%$ of total segments, respectively. While Ulocladium sp. was recovered only from region 40 represented by $1.41 \%$ of total colonies and $0.56 \%$ of total segments.

\section{Antimicrobial assay}

Thirty nine isolates of endophytic fungi were randomly chosen to estimate their ability to produce antimicrobial compounds (antibacterial or antifungal activity). The estimation was done on four bacteria species by disc diffusion method, which were incubated at $37^{\circ} \mathrm{C}$ for $24 \mathrm{hr}$ and inhibition zones were measured. And also, two fungal species were tested by disc diffusion method, which were incubated at $28^{\circ} \mathrm{C}$ for 5-7 days and inhibition zones were measured. These isolates comprised from A. nidulans, A.niger, A. terreus, Phoma sp., and sterile mycelium 3, 5, 6, 8 and 9 (one isolate for each species), Acromonium sp., A. flavus and Chaetomium globosum (2 isolates for each species), sterile mycelia 2 and 4 ( 3 isolates for each species), 4 isolates of sterile mycelia 7 and 9 isolates of sterile mycelium no.1.

The obtained results indicated that all tested isolates did not have any effect on fungal species in comparison with positive control, while some isolates of the same species exhibit different behavior against used bacteria and few of these isolates of the same species showed the same behavior (Table 2).

From 39 tested isolates of endophytic fungi, 23 isolates inhibit the growth of Bacillus subtilis. Sterile mycelium no. (1) showed the highest effect on $B$. subtilis (17/17 $\mathrm{mm}$ for positive control), whereas the lowest effect was recorded by sterile mycelia 1 and $2(6 \mathrm{~mm})$. While 8 isolates only effected on Staphylococcus aureus, which had high value than control in some species, the highest effect on Staphylococcus aureus occur by sterile mycelia 7, 5 and Acromonium sp. (26, 23 and $21 \mathrm{~mm}$, respectively, than positive control 17mm) and the lowest effect for sterile mycelium no.1 (11mm). (Table 2). 
TABLE 2. Antimicrobial activities of endophytic fungi from Avicennia marina.

\begin{tabular}{|c|c|c|c|c|c|c|c|}
\hline \multirow{2}{*}{\multicolumn{2}{|c|}{$\begin{array}{l}\text { Endophytic species and } \\
\text { isolates }\end{array}$}} & \multicolumn{6}{|c|}{ Antimicrobial activity } \\
\hline & & \multirow{2}{*}{\begin{tabular}{|c|} 
Bacillus \\
subtilis \\
- \\
\end{tabular}} & \multirow{2}{*}{\begin{tabular}{|c|}
$\begin{array}{c}\text { Staphylococcus } \\
\text { aureus }\end{array}$ \\
- \\
\end{tabular}} & \multirow{2}{*}{\begin{tabular}{|c|}
$\begin{array}{c}\text { Micrococcus } \\
\text { luteus }\end{array}$ \\
- \\
\end{tabular}} & \multirow{2}{*}{\begin{tabular}{|c|}
$\begin{array}{c}\text { Escherichia } \\
\text { coli }\end{array}$ \\
- \\
\end{tabular}} & \multirow{2}{*}{\begin{tabular}{|c|}
$\begin{array}{c}\text { Aspergillus } \\
\text { niger }\end{array}$ \\
- \\
\end{tabular}} & \multirow{2}{*}{\begin{tabular}{|c|}
$\begin{array}{r}\text { Alternaria } \\
\text { alternata }\end{array}$ \\
- \\
\end{tabular}} \\
\hline Acromonium sp. & Isolate 1 & & & & & & \\
\hline \begin{tabular}{|l|}
$\begin{array}{l}\text { Chaetomium } \\
\text { globosum }\end{array}$ \\
\end{tabular} & Isolate 1 & 8 & 13 & 16 & - & - & - \\
\hline Sterile 7 & Isolate 1 & 16 & 26 & 14 & - & - & - \\
\hline A. niger & & - & - & - & - & - & - \\
\hline A. terreus & & - & - & - & - & - & - \\
\hline Sterile 1 & Isolate 1 & 6 & - & - & - & - & - \\
\hline Sterile 7 & Isolate 2 & - & - & - & - & - & - \\
\hline Sterile 8 & Isolate 1 & - & - & - & - & - & - \\
\hline Sterile 8 & Isolate 2 & - & - & - & - & - & - \\
\hline Sterile 6 & & - & - & - & - & - & - \\
\hline Sterile 5 & & 14 & 23 & 15 & 6 & - & - \\
\hline Sterile 3 & & 14 & - & - & - & - & - \\
\hline Sterile 8 & Isolate 3 & - & - & - & - & - & - \\
\hline A. flavus & Isolate 1 & - & - & - & - & - & - \\
\hline Phoma sp. & & - & - & - & - & - & - \\
\hline Sterile 1 & Isolate 2 & 7 & - & - & - & - & - \\
\hline A. flavus & Isolate 2 & 7 & 13 & - & - & - & - \\
\hline Sterile 7 & Isolate 3 & 12 & - & - & - & - & - \\
\hline Sterile 2 & Isolate 1 & 6 & - & - & - & - & - \\
\hline Sterile 1 & Isolate 3 & 11 & - & - & - & - & - \\
\hline Sterile 8 & Isolate 4 & 7 & - & - & - & - & - \\
\hline Sterile 1 & Isolate 4 & 12 & - & - & - & - & - \\
\hline Sterile 8 & Isolate 5 & 11 & - & - & - & - & - \\
\hline A. nidulans & & 12 & - & - & - & - & - \\
\hline Sterile 4 & Isolate 1 & 9 & 17 & 17 & - & - & - \\
\hline Sterile 7 & Isolate 4 & 12 & 14 & - & - & - & - \\
\hline Sterile 1 & Isolate 5 & 15 & - & 22 & 8 & - & - \\
\hline $\begin{array}{l}\text { Chaetomium } \\
\text { globosum }\end{array}$ & Isolate 2 & 8 & - & - & - & - & - \\
\hline Sterile 8 & Isolate 6 & 9 & - & - & - & - & - \\
\hline Sterile 4 & Isolate 2 & - & - & - & - & - & - \\
\hline Acromonium sp. & Isolate 2 & 11 & 21 & - & - & - & - \\
\hline Sterile 1 & Isolate 6 & 8 & - & 21 & - & & \\
\hline Sterile 1 & Isolate 7 & 17 & - & - & - & - & - \\
\hline Sterile 9 & & 9 & - & 18 & - & - & - \\
\hline
\end{tabular}

Egypt. J. Microbiol. 47 (2012) 
TABLE 2. Cont.

\begin{tabular}{|c|c|c|c|c|c|c|c|}
\hline \multirow{2}{*}{\multicolumn{2}{|c|}{$\begin{array}{l}\text { Endophytic species and } \\
\text { isolates }\end{array}$}} & \multicolumn{6}{|c|}{ Antimicrobial activity $^{\mathrm{a}}$} \\
\hline & & \multirow{2}{*}{\begin{tabular}{|c|}
$\begin{array}{c}\text { Bacillus } \\
\text { subtilis }\end{array}$ \\
- \\
\end{tabular}} & \multirow{2}{*}{\begin{tabular}{|c|}
$\begin{array}{c}\text { Staphylococcus } \\
\text { aureus }\end{array}$ \\
- \\
\end{tabular}} & \multirow{2}{*}{\begin{tabular}{|c|}
$\begin{array}{c}\text { Micrococcus } \\
\text { luteus }\end{array}$ \\
- \\
\end{tabular}} & \multirow{2}{*}{$\begin{array}{c}\begin{array}{c}\text { Escherichia } \\
\text { coli }\end{array} \\
- \\
\end{array}$} & \multirow{2}{*}{\begin{tabular}{|c|}
$\begin{array}{c}\text { Aspergillus } \\
\text { niger }\end{array}$ \\
- \\
\end{tabular}} & \multirow{2}{*}{$\begin{array}{c}\begin{array}{c}\text { Alternaria } \\
\text { alternata }\end{array} \\
- \\
\end{array}$} \\
\hline Sterile 2 & Isolate 2 & & & & & & \\
\hline Sterile 1 & Isolate 8 & 13 & 11 & - & - & - & - \\
\hline Sterile 1 & Isolate 9 & - & - & 16 & - & - & - \\
\hline Sterile 2 & Isolate 3 & 13 & - & - & - & - & - \\
\hline Sterile 4 & Isolate 3 & - & - & - & - & - & - \\
\hline \multicolumn{2}{|c|}{ Positive control $^{\mathrm{b}}$} & 17 & 17 & 14 & 15 & 10 & 7 \\
\hline
\end{tabular}

${ }^{\mathrm{a}}$ The antimicrobial activity is expressed by the diameter $(d)$ of inhibition zone $(\mathrm{mm}){ }^{\mathrm{b}}{ }^{\mathrm{b}}$ Control for Gram +ve is chloroamphenicol $\left(1 \times 10^{-3}\right)$, for Gram -ve is tetracycline $\left(1 \times 10^{-3}\right)$ and for fungal species is kemazed 50\% ( methyl benzimidazol-2-ylcarbamate) $\left(1 \times 10^{-3}\right)$.

Also 8 isolates were showed inhibition for growth of Micrococcus luteus, as they sterile mycelium No. (1, 4, 5, 7 and 9) and Chaetomium globosum. The highest effect was evident through sterile mycelium no. (1) ( $22 / 14 \mathrm{~mm}$ ), whereas the lowest effect was revealed by sterile mycelium no. 7 (14/14 mm).

On the other hand, these compounds show weak effect on Escherichia coli (2/ 39), where sterile mycelium 5 which showed clear zone $(6 \mathrm{~mm})$ while, it was estimated by $(8 \mathrm{~mm})$ for one isolate of sterile mycelium no. 1 .

\section{Discussion}

The endophytic fungi are the type of the most diverse group of organisms that have symbiotic relationship with higher plants, and have the ability to secrete substances beneficial to plant (Weber, 1981 and Shiomi et al., 2006 ).

Endophytic organisms have received considerable attention after they were found to protect their host against insect pests, pathogens and even domestic herbivorous (Weber, 1981). However only a few plants have been studied for their endophyte biodiversity and their potential to produce bioactive compounds. Recently studies have been carried out about the endophytic bio-diversity, taxonomy, reproduction, host ecology and their effort on host (Petrini, 1986 ; Arnold et al., 2001 and Clay \& Schardl, 2002). Endophytes, are now considered as an out standing source of bioactive natural products, because they occupy unique biological niches as they grow in so many unusual environments (Strobel \& Daisy, 2003).

In the present study mainly Acromonium sp., Aspergillus sp.,Chaetomium sp., Cladosporium sp. Fusarium sp., Phoma sp., Ulocladium sp. and sterile mycelium were isolated as endophytic fungi. Majority of endophytic fungi belonged to Ascomycetes and Deutromycetes (Frohlich \& Hyde, 1999; Kumaresan \& Suryanarayanan, 2002 and Bharathidasan \& Panneerselvam, 2011). 
It can be seen from this part of the study that, the extracts of endophytic fungi, had no effect on pathogenic fungi. But these extracts had appeared highest effect against some bacteria species (Bacillus subtilis, Staphylococcus aureus and Micrococcus luteus ). The results also showed that the Gram-positive bacteria were the most sensitive than Gram-negative bacteria. Where, Shan et al. (2007) showed that among the five bacteria tested against 46 hydrophobic extracts, $S$. aureus was the most sensitive bacteria, while $E$. coli was the most resistant. The highest sensitivity of $B$. subtilis and $S$. aureus may be due to its cell wall structure and outer membrane (Zaika, 1988; Ceylan \& Fung, 2004 and Lopez et al., 2005). A possible explanation for this observation may be due to presence of an outer membrane and a unique periplasmic space in Gram - and not found in Gram-positive bacteria (Nikaido,1996 and Duffy \& Power, 2001).

\section{References}

Ananda, K. and Sridhar, K.R. (2002) Diversity of endophytic fungi in the roots of mangrove species on west coast of India. Canadian Journal of Microbiology, 48, 871- 878.

Arnold, A.E., Maynard, Z. and Gilbert, G.S. (2001) Fungal endophytes in dicotyledonous neotropical trees: patterns of abundance and diversity. Mycological Research, 105, 1502- 1507.

Bacon, C.W. and White, J.F. (2000) "Microbial Endophytes". pp.487. Marcel Dekker, Inc, New York.

Bandaranayake, W.M. (1998) Traditional and medicinal uses of mangroves. Mangrove and Salt Marshes, 2, 133- 148.

Bharathidasan, R. and Panneerselvam, A. (2011) Biodiversity of the endophytic fungi isolated from Avicennia marina in Ramanathapuram district, Karankadu. World Journal of Science and Technology, 1 (9),1- 5.

Bauer, A.W., Kirby, W.M.M., Sherris, J.C. and Truck, M. (1966) Antibiotic susceptibility testing by standardized single disc method, American Journal of Clinical Pathology, 45, 493- 496.

Carroll, G.C. (1986) The biology of endophytism in plants with particular reference to woody perennials. In: "Microbiology of the Phylloshere" N.J. Fokkema \& J. Van den Meurel. (Ed.), pp. 205-222. Cambridge University Press, Cambridge, U.K.

Ceylan, E. and Fung, D.Y.C. (2004) Antimicrobial activity of spices. Journal of Rapid Methods and Automation in Microbiology, 12, 1- 55.

Clay, K. and Schardl, C. (2002) Evolution origins and ecological consequences of endophyte symbiosis with grasses. The American Naturalist, 160, 99- 127.

Ding, T., Jiang, T., Zhou, J., Xu, L. and Gao, Z.M. ( 2010) Evaluation of antimicrobial activity of endophytic fungi from Camptotheca acuminata (Nyssaceae). Genetics. and Molecular Research, 9 (4), 2104- 2112.

Egypt. J. Microbiol. 47 (2012) 
Duffy, C.F. and Power, R.F. (2001) Antioxidant and antimicrobial properties of some Chinese plant extracts. International Journal of Antimicrobial Agents, 17, 527- 529.

Dunk, N.C., Ball, M.C. and Ellison, J.C. (1998) Factors influencing biodiversity and distribution gradients in mangrove. Global Ecology and Biodiversity Letters, 7, 2747.

Ellison, A.M., Farnsworth, E.J. and Merkt, R.E. (1999) Origins of mangrove ecosystem and the mangrove biodiversity anomaly. Global Ecology and Biogeography, 8, 95- 115.

Ellison, A.M. and Farnsworth, E.J. (2001) Mangrove communities. In: "Marine Community Ecology" Bertness, M.D., S.D. Gaines, M.E. Hay (Ed.). Sinauer, Sunderland, Mass. pp. 423- 442.

Ezawa, S. and Tada, Y. (2009) Identification of salt tolerance genes from the mangrove plant Bruguiera gymnorhiza using Agrobacterium functional screening. Plant Science, 176, 272- 278.

Filip, P., Weber, R.W.S., Sterner, O. and Anke, T. (2003) Hormonemate, a new cytotoxic and apoptosis-inducing compound from the endophytic fungus Hormonema dematioides. 1. Identification of the producing strain, isolation and biological properties of hormonemate. Zeitschrift für Naturforschung, 58, 547- 552.

Fisher, P.J. and Petrini, O. (1987) Location of fungal endophytes in tissues of Suaeda fruticosa: A preliminary study. Transactions of the British Mycological Society, 89, 246- 249.

Fröhlich, J. and Hyde, K.D. (1999) Biodiversity of palm fungi in the tropics: are global fungal diversity estimates realistic? Biodiversity and Conservation, 8, 977- 1004.

Grant, W.D., Atkinson, M., Burke, B. and Molly, C. (1996) Chitinolysis by the marine ascomycete Corollospora maritima Werdermann: purification and properties of chitobiosidase. Botaica Marina, 39, 177- 186.

Hawksworth, D.L., Sutton, B.C. and Ainsworth, G.C. (1983) "Ainsworth and Bisby's Dictionary of the Fungi". Commonwealth Mycological Insti Kew, Surrey, England, p.445.

Kathiresan, K. and Bingham, B.L. (2001) Biology of mangrove and mangrove ecosystems. Advances in Marine Biology, 40, 81- 251.

Kumaresan, V. and Suryanarayanan, T.S. (2002) Endophyte assemblages in young, mature and senescent leaves of Rhizophora apiculata: evidence for the role of endophytes in mangrove litter degradation. Fungal Diversity, 9, 81- 91.

Li, L ., Sattler, I., Deng, Z., Groth, I., Walther, G., Menzel, K., Peschel, G., Grabley, S. and Lin, W. (2008) A-seco-oleane-type triterpenes from Phomopsis sp. (strain HKI0458) isolated from the mangrove plant Hibiscus tiliaceus. Phytochemistry, 69, 511- 517. 
Lin, X., Lu, C. and Ye, Y. (2009) Toxicity of crude extracts from several terrestrial plants to barnacle larvae on mangrove seedlings. Ecological Engineering, 35(4), 502510 .

Lin, Y., Wu, X., Feng, S., Jiang, G., Luo, J., Zhou, S., Vrijmoed, L.L.P., Jones, E.B.G., Krohn, K., Steongröver, K. and Zsila, F. (2001) Five unique compounds: xyloketales from mangrove fungus Xylaria sp. from the South China Sea Coast. Journal of Organic Chemistry, 66, 6252- 6256.

Lopez, P., Sanchez, C., Batlle, R. and Nerin, C. (2005) Solid and vapor-phase antimicrobial activities of six essential oils: susceptibility of selected foodborne bacterial and fungal strains. Journal of Agricultural and Food Chemistry, 53, 69396946.

Maria, G.L., Sridhar, K.R. and Raviraja, N.S. (2005) Antimicrobial and enzyme activity of mangrove endophytic fungi of southwest coast of India. Journal of Agricultural Technology, 1, 67-80.

Nelson, P.E., Toussoun, T.A. and Marasas, W.F.O. (1983) "Fusarium Species, an Illustrated Manual for Identification". The Pennsylvania State University Press, USA, p. 193.

Nikaido, H. (1996) Outer membrane. In: "Escherichia coli and Salmonella typhimurium: Cellular and Molecular Biology" Neidhardt, F.C. (Ed.). American Society for Microbiology Press, Washington, D. C, pp. 29- 47.

Petrini, O. (1986) Taxonomy of endophytic fungi of aerial plant tissues. In: "Microbiology of the Phylosphere". N.J. Fokkenna, J. Van Den Heuvel (Ed.). pp.175187. Cambridge University Press, Cambridge.

Petrini, O., Sieber, T.N., Toti, L. and Vivet, O. (1992) Ecology, metabolite production and substrate utilisation in endophytic fungi. Natural Toxins, 1, 185- 196.

Pointing, S.B. and Hyde, K.D. (2000) Lignocellose-degrading marine fungi. Biofouling, 15, 221- 229.

Pointing, S.B., Vrijmoed, L.L.P. and Jones, E.B.G. (1998) A qualitative assessment of lignocellulose degrading enzyme activity in marine fungi. Botanica Marina, 41, 293298.

Ramos, H.P., Braun, G.H., Pupo, M.T. and Said, S. (2010) Antimicrobial activity from endophytic fungi Arthrinium state of Apiospora montagnei Sacc. and Papulaspora immerse. Brazilian Archives of Biology and Technology, 53( 3), 629- 632.

Ricklefs, R.E. and Latham, R.E. (1993) Global pattern of diversity in mangrove floras. In: "Species Diversity in Ecological Communities Historical and Geographical Perspectives". Ricklefs, R.E., Schluter, D. (Ed.) pp.215- 233. Chicago, USA: University of Chicago Press,

Saenger, P. (2002) Ecological assessment of mangroves in Egypt. Consultancy report, TCP/EGY/0168A, FAO, Cairo. (unpublished report), 29.

Egypt. J. Microbiol. 47 (2012) 
Shan, B., Cai, Y.Z., Brooks, J.D. and Corke, H. (2007) The in vitro antibacterial activity of dietary spice and medicinal herb extracts. International Journal of Food Microbiology, 117, 112- 119.

Shiomi, H.F., Silva, H.S.A., De Melo, I.S., Nunes, F.V. and Bettiol, W. (2006) Bioprospecting endophytic bacteria for biological control of coffee leaf rust. Scientia Agricola, 63(1), 32- 39.

Singh, H.S. (2000) Mangroves in Gujarat. Current status and strategy for conservation. GEER Foundation, Gandhinagar, 128.

Strobel, G. and Daisy, B. (2003) Bioprospecting of microbial endophytes and their natural products. Microbiology and Molecular Biology Reviews, 67(4), 491- 502.

Strobel, S.A. (2002) Biochemical identification of A-minor motifs within RNA tertiary structure by interference analysis. Biochemical Society Transactions, 30, 1126- 1131.

Sun, Z., Zhang, M., Zhang, J. and Feng, J. (2011) Antifungal and cytotoxic activities of the secondary metabolites from endophytic fungus Massrison sp. Phytomedicine, 18, 859- 862 .

Suryanarayanan, T.S. (1992) Light incubation: A neglected procedure in mycology. The Mycologist, 6, 144.

Sutton, B.C. (1980) The Coelomycetes. Commonwealth Mycological Institute. Synthesis and effect of silver nanoparticles on the antibacterial activity of different antibiotics against Staphylococcus aureus and Escherichia coli. Nanome. Nanotechnology, Biology and Medicine, 3, 168- 171.

Tomlinson, P.B. (1986) "The Botany of Mangroves". London, UK: Cambridge University Press. p.419.

Von Arx, J.A., Guarro, J. and Figueras, M.J. (1986) The ascomycetes genus Chaetomium. J . Cramer, In der Gebrüder Borntraeger Verlagsbuchhandlung Berlin. Stuttgart, 1,162.

Wasser, S.P. (2002) Medicinal mushrooms as a source of anti-tumor and immunomodulating polysaccharides. Applied Microbiology and Biotechnology, 60, 258- 274.

Weber, J. (1981) A natural control of Dutch elm disease. Nature, London, 292, 449- 451.

Zaika, L.L. (1988) Spices and herbs- their antimicrobial activity and its determination. Journal of Food Safety, 9, 97- 118.

Zakaria, L., Foong, M.K., Hsuan, H.M., Zakaria, M. and Salleh, B. (2010) Fusarium species isolated from mangrove soil in Kampung Pantai Acheh, Balik Pulau, Pulau Pinang, Malaysia. Tropical Life Sciences Research, 21(1), 21- 29.

(Received 30/11/2011;

accepted $8 / 2$ / 2012)

Egypt. J. Microbiol. 47 (2012) 


\section{النشاط الميكروبي للفطريات الداخلية المعزولـة من نبات ابن سينا.

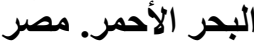

$$
\text { قسم النبات - كليه العلوم بقناء جامعه جنوب الو ادي_ قنا - مصر. }
$$

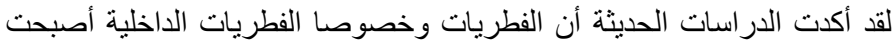

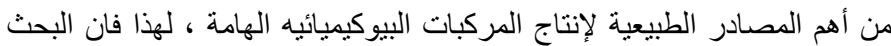

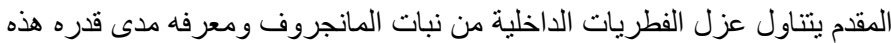
الفطريات على إنتاج مركبات مثبطه لنمو بعض من نبات أنواع البكتيريا و الفطريات.

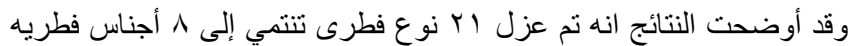

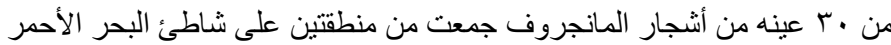

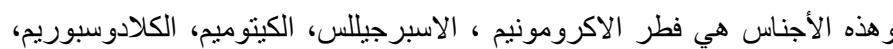

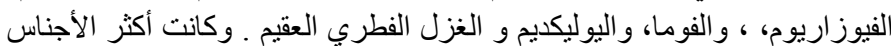
شيوعا هو الغزل الفطري العقيم يليه فطر الاسبرجيلئس.

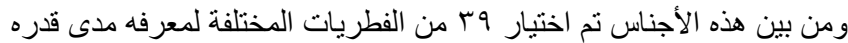

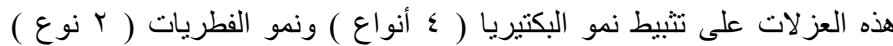

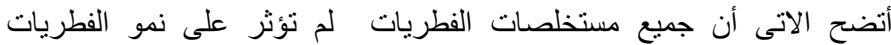

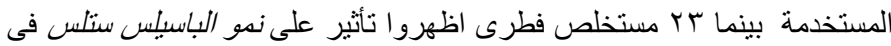

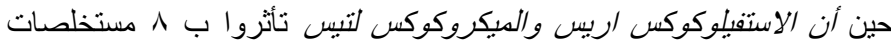

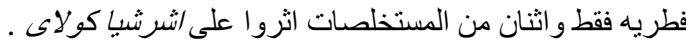

